\title{
Effects of transportation induced stress in electrocardiography data and blood parameters in Kangal Akkaraman sheep breed
}

\author{
Mustafa KOÇKAYA
}

Sivas Cumhuriyet University, Faculty of Veterinary Medicine, Department of Veterinary Physiology, 58140, Sivas/TURKEY

\section{Key Words: \\ electrocardiography \\ blood parameters \\ Kangal Akkaraman sheep \\ transportation \\ welfare levels \\ Received: 26.03.2019 \\ Accepted: 15.05.2019 \\ Published Online: 30.06.2019 \\ Article Code: 544947 \\ Correspondence: \\ M. KOÇKAYA \\ (vet_mustafakockaya@hotmail.com)}

ORCID:

M. KOÇKAYA: 0000-0001-5173-0853

\begin{abstract}
The objective of the study was to investigate the stress effects induced by transportation in blood parameters and in electrocardiography data in Kangal Akkaraman sheep breed. Clinically healthy 36 Kangal Akkaraman sheep were used in the study. Electrocardiography data from the sheep were obtained by holder device during the resting period, and during 30 minute and 120 minute transportation periods. Blood parameters were determined from serum samples obtained during resting period, and after 30 minute and 120 minute transportations. Significant differences were obtained in the durations both PR to QT interval and P-wave, in the amplitude of P-wave, in heart pulse count per minute, and serum glucose levels in groups of resting and 30 min transportation, and resting and 120 transportation, and $30 \mathrm{~min}$ transportation and $120 \mathrm{~min}$ transportation. Significant differences were obtained for durations of both the QRS complex and T-wave in groups of resting and $30 \mathrm{~min}$ transportation, and of $30 \mathrm{~min}$ transportation and $120 \mathrm{~min}$ transportation. Significant differences were obtained for serum total protein, albumin, and creatinine levels in groups of resting and $120 \mathrm{~min}$ transportation, and 30 min transportation and 120 min transportation. No significant difference was obtained for serum blood urea nitrogen levels between study groups. This study is the first in literature where the effects of transportation induced stress in electrocardiography data and blood parameters in Kangal Akkaraman breed sheep were investigated.
\end{abstract}

\section{INTRODUCTION}

Sheep husbandry in Turkey is generally maintained in non-agricultural plains and in pastoral countryside. Sheep husbandry is contributing to the national economy and the feeding of the populace by providing meat, milk, and wool products. Kangal Akkaraman sheep breed contributes to $45.8 \%$ of all sheep population in Turkey $(2,12,20)$.

Transportation of livestock is one of the critical elements conducted in agricultural establishments, and is one of the factors that affects the wellness of animals by inducing stress factors in animals $(8,13,14,15,23)$. Stress as a term is described as the behavioral, physiological, and mental responses from the animal against anything that perceived as a threat (30). Transportation duration is the crucial factor that determines the stress inducement from the transportation. Especially animals that are not used to transportation would be affected by intensive stress during the first hours of the transportation (4). Such a condition in turn results in certain physiological and biochemical responses displayed by animals. Once the stress is induced, alterations in many physiological and biochemical parameters become apparent due to the activities of sympathetic nervous system and hormonal changes $(9,24)$. Metabolic alterations caused by the transportation induced stress can be determined by the detection of changes in physiological ranges of certain biochemical molecules in the blood $(3,18,21)$
During the initial hours of the transportation, heart pulse rates of sheep are known to be increased, which was stated to occur due to induced stress in animals (17). Electrocardiography (ECG) is a method that records the action potentials of the heart during its pulsing which enables the evaluation of the action potentials and the electrical activity of the heart along with some degree of its functional state (32). By utilizing the ECG method, many physiological conditions related to the heart can be determined $(7,22,26,29)$. No study was found in literature related to the physiological parameter changes caused by transportation induced stress in Kangal Akkaraman sheep breed.Therefore in this study, it was aimed to investigate the effects of the transportation induced stress in Kangal Akkaraman sheep breed in both blood parameters and ECG data.

\section{MATERIALS and METHODS}

The sheep used in the study were obtained from the sheep husband Mehmet Sahin in Sivas province. A total of 36 clinically healthy Kangal Akkaraman sheep aging between 1 to 3 years were selected. Animal experimantations were approved by the Local Ethics Committee for Animal Experimentations of Cumhuriyet University with issue number of 65202830050.04.04-248 in February 21, 2019.

The ECG data of the sheep were recorded by using holder device (Televet II, KRUUSE, Denmark) in their resting perio- 
Table 1. Differences in the ECG data obtained from the sheep in their resting periods, and during 30 and 120 minutes transportations.

\begin{tabular}{|c|c|c|c|c|c|}
\hline ECG datas & $\mathbf{N}$ & $\begin{array}{l}\text { Resting state } \\
(\text { Mean } \pm \text { SEM })\end{array}$ & $\begin{array}{c}30 \mathrm{~min} . \\
(\text { Mean } \pm \mathrm{SEM})\end{array}$ & $\begin{array}{c}120 \text { min. } \\
(\text { Mean } \pm \mathrm{SEM})\end{array}$ & P value \\
\hline$P$ wave duration $(\mathrm{s})$ & 36 & $0,042 \pm 0,000222^{\mathrm{a}}$ & $0,038 \pm 0,000276^{\mathrm{b}}$ & $0,040 \pm 0,000314^{c}$ & $<0,001$ \\
\hline P wave amplitude (mV) & 36 & $0,221 \pm 0,000561^{\mathrm{a}}$ & $0,184 \pm 0,000384^{\mathrm{b}}$ & $0.191 \pm 0.000494^{c}$ & $<0,001$ \\
\hline QRS complex duration (s) & 36 & $0,069 \pm 0,000120^{\mathrm{a}}$ & $0,068 \pm 0,000113^{\mathrm{b}}$ & $0,069 \pm 0,000120^{\mathrm{a}}$ & $<0,001$ \\
\hline PR intervals duration (s) & 36 & $0,144 \pm 0,000898^{\mathrm{a}}$ & $0,126 \pm 0,000897^{\mathrm{b}}$ & $0,135 \pm 0,000813^{c}$ & $<0,001$ \\
\hline QT intervals duration (s) & 36 & $0,205 \pm 0,000538^{\mathrm{a}}$ & $0,198 \pm 0,000447^{\mathrm{b}}$ & $0,204 \pm 0,000329^{c}$ & $<0,001$ \\
\hline Heart rate (bpm) & 36 & $131,03 \pm 0,773^{a}$ & $180,00 \pm 1,076^{\mathrm{b}}$ & $143,00 \pm 0,556^{c}$ & $<0,001$ \\
\hline
\end{tabular}

SEM: standard error of mean, N: number of Kangal Akkaraman sheep mm: millimeter, s: second, mV: millivolt, bpm: beats per minute, min: minute a, b, c: Superscripts denotes the statistical significance.

ds, and during 30 minutes and 120 minutes transportation periods. Blood samples from the jugular vena of the sheep were collected into yellow capped gel coated hematological tubes in their resting periods, and after 30 minutes and 120 minutes long transportations. Fixation of the holder device and the electrodes was done by using mesh bandages. To eliminate the variations in both the ECG data and blood parameters that could be caused by different environmental conditions, the ECG recordings and blood sampling were conducted in all sheep in the same environmental condition. To prevent the manipulation stress, fixation of holder device and electrodes using mesh bandages was previously exercised. Both the device and the aqua-wet gel electrodes were attached to the sheep as per the instructions provided by the manufacturer and fixated by using mesh bandages. Derivations of Einthoven I, II, and II were printed. The P-wave duration and amplitude, QRS complex duration, T-wave duration, PR and QT intervals duration, and heart pulse count were determined in the second derivations of the obtained electrocardiograms. and intergroup differences were determined by using Paired Samples t-Test. All the tests were conducted by using the SPSS v.22 package software (27).

\section{RESULTS}

In Table 1, differences in the ECG data obtained from the sheep in their resting periods, and during 30 minutes and 120 minutes transportation periods were shown. For each group shown, significant differences were observed for the durations of PR, QT intervals and P-wave, T-wave and QRS complex, in P-wave amplitude, and in heart pulse count per minute. When compared to the resting period values, durations of PR, QT intervals and the P-wave were observed as shorter in 30 and 120 minutes transportation groups, and these datas were observed as shorter in 30 minutes transportation group compared to the 120 minutes transportation group. These differences were determined as significant $(\mathrm{P}<0.001, \mathrm{P}<0.01)$. Amplitudes of the $\mathrm{P}$-wave were observed as shorter in 30 minutes transportation

Table 2. Differences in the blood serum levels obtained from the sheep in their resting periods, and after the 30 and 120 minutes transportations

\begin{tabular}{|c|c|c|c|c|c|}
\hline & & Resting state & 30 min. & $120 \mathrm{~min}$. & \\
\hline Blood Serum Parameters & $\mathbf{N}$ & $($ Mean \pm SEM $)$ & $($ Mean \pm SEM $)$ & $($ Mean \pm SEM $)$ & $P$ value \\
\hline Glucose $(\mathrm{mg} / \mathrm{dL})$ & 36 & $64.47 \pm 1.03^{\mathrm{a}}$ & $107.94 \pm 0.75^{\mathrm{b}}$ & $92.78 \pm 1.03^{c}$ & $<0.001$ \\
\hline Total Protein(g/dL) & 36 & $5.89 \pm 0.04^{a}$ & $5.90 \pm 0.04^{\mathrm{a}}$ & $6.68 \pm 0.09^{\mathrm{b}}$ & $<0.001$ \\
\hline Albumine (g/dL) & 36 & $2.76 \pm 0.02^{\mathrm{a}}$ & $2.76 \pm 0.02^{\mathrm{a}}$ & $3.32 \pm 0.03^{b}$ & $<0.001$ \\
\hline Blood Urea Nitrogen $(\mathrm{mg} / \mathrm{dL})$ & 36 & $18.56 \pm 0.71$ & $18.29 \pm 0.80$ & $19.08 \pm 0.73$ & $>0.05$ \\
\hline Creatinin $(\mathrm{mg} / \mathrm{dL})$ & 36 & $1.21 \pm 0.01^{\mathrm{a}}$ & $1.21 \pm 0.01^{\mathrm{a}}$ & $1.23 \pm 0.01^{\mathrm{b}}$ & $<0.05$ \\
\hline
\end{tabular}

SEM: standard error of mean, $\quad$ N: number of Kangal Akkaraman sheep mg: milligram, $\quad$ g: gram, $\quad$ dl: deciliter, min: minute a, b, c: Superscripts denotes the statistical significance.

Blood glucose, total protein, albumine, blood urea nitrogen, and creatinine levels in obtained blood serum samples were determined by using biochemical autoanalyzator (Mindray BS200, PRC).

\section{Statistical Analyses}

Mean and standard error values of all groups were given group as compared to both resting periods and 120 minutes transportation. The same data in 120 minutes transportation was observed as shorter as compared to resting periods. These differences were determined as significant $(\mathrm{P}<0.001)$. Both the durations of QRS complex and T-wave during 30 minutes transportation were observed as shorter compared to resting periods and in 120 minutes transportation, and the difference was significant $(\mathrm{P}<0.001)$. Heart pulse count per minutes 
values in both 30 and 120 minutes transportations were observed as higher compared to resting periods. The same data in 30 minutes transportation were observed as higher compared to 120 minutes transportation. These differences were determined as significant $(\phi<0.001)$.

In Table 2, differences in the blood serum levels obtained from the sheep in their resting periods, and after the 30 minutes and 120 minutes transportation periods were shown. Significant differences for each group were determined in blood glucose levels. Blood serum glucose levels in resting periods were observed lower compared to both 30 and 120 minutes transportation periods. Blood serum glucose levels after 120 minutes transportations were observed as lower compare to 30 minutes transportation. These differences were determined as significant $(\mathrm{P}<0.001)$. After 120 minutes transportation serum total protein, albumin, and creatinine levels were observed as higher compared to the values from the resting periods and after 30 minutes transportation. These differences were determined as significant $(\mathrm{P}<0.001, \mathrm{P}<0.05$, $\mathrm{P}<0.01)$. No significant difference was determined for serum blood urea nitrogen levels in each group $(\mathrm{P}>0.05)$.

\section{DISCUSSION}

Transportation is a process that includes stress inducing physiological stimulants which results in alterations in both metabolism and homeostasis of affected animals $(6,25,31)$. It was stated that the plasma cortisol levels of sheep elevates significantly in the first 20 minutes of the transportation and stays elevated for the first 24 hours after the transportation $(4,11)$. This indicates that the stress inducement significantly elevates certain physiological parameters, these parameters alter in the first 20 minutes of the transportation. Several studies reported that the heart pulse count per minute elevates initially during the transportation, then gradually decreases from the elevated counts in the first 30 to 60 minutes of the transportation, and becomes fixated in 10 to $25 \%$ higher than normal rates $(5,8$, 16). In our study, the highest heart pulse counts were obtained during the 30 minutes transportation which were higher than the 120 minutes transportation counts. Similarly, heart pulse counts during the 120 minutes transportation were higher than the counts in resting periods. These results are in accordance with the available literature, and it is thought that the significant increase of heart pulse counts in the first 30 minutes of transportation was due to the transport induced stress. Gradual decrease in heart pulse counts in later stages of the transportation was thought to be due to adaptation of animals to the transportation. It was stated that the ECG data could be altered according to factors that would change the heart pulse counts per minutes such as age, gender, stress, drug administration etc. $(1,10,22,26,28)$. Different studies reported in their respective studies that the durations of $\mathrm{P}$ and T-waves, QRS complex, PR, QT, and ST intervals, the amplitudes of P and $\mathrm{T}$-waves decrease when the heart pulse counts per minute increase $(10,22,28)$. Similarly in our study, the groups of higher heart pulse counts per minutes were provided with shorter durations for P and T-waves, QRS complex, PR and QT intervals, and with lower amplitude for P-wave.
Noyan (2008) stated that the stress results in various physiological and biochemical changes like increases in blood glucose levels due to the activity of symphatetic nervous system and the hormonal changes. Previous studies indicated that the transportation of animals results in changes in various blood parameters (3-5, 8, 19, 21, 23). Ali-Gholi et al. (2007) reported that the blood glucose levels increase during the initial stages of the transportation, then gradually decrease but stay fixed in higher levels compared to pre-transportation levels. In the present study, the blood glucose levels obtained after the $30 \mathrm{mi}-$ nutes transportation were the highest, while the blood glucose levels obtained after 120 minutes transportation were higher compared to resting period levels. Many studies reported in their respective studies that levels of serum total protein, albumin, and creatinine increase as the duration of the transportation increases $(19,21,23)$. Similarly, these values in our study obtained after 120 minutes transportation were higher compared to other groups. Even though Haydardedeoglu et al. (2017) reported that the blood urea nitrogen levels would increase as the transportation duration increases, in our study no significant difference was determined for blood urea nitrogen levels for each group. This was attributed to the shorter duration transportation in our study compared to others.

In conclusion, it was determined that the ECG data and blood parameters change in Kangal Akkaraman sheep breed by transportation induced stress in relation to the transportation duration. It would be beneficial to take these parameters into consideration for animal transportations.

\section{REFERENCES}

1. Ahmed JA, Sanyal S. Electrocardiographic studies in garol sheep and black bengal goats. Res J Cardiol. 2008;1:1-8.

2. Akçapınar H. Koyun yetiştiriciliği. Yenilenmiş 2. Baskı. Ankara:İsmat Matbac1lik; 2000.

3. Ali Gholi R, Siamak AR, Daryoush M. Influence of the short-term road transport stress on blood parameters in cows. Medycyna Wet. 2007;63:1311-1315.

4. Altınçekiç ŞÖ, Koyuncu M. Nakil koşullarının hayvan refahı üzerine etkileri. J Anim Prod. 2010;51:48-56.

5. Andronie I, Parvu M, Andronie V. The effects of transport stress on sheep welfare. Lucrări stiintifice Zootehnie si Biotehnologii. 2000;41:729-734.

6. Andronie I, Parvu M, Andronie V, Ciurea A. Effects of transportation stress on some physiological indicators in sport horses. J Zootech Bio. 2009;42:379-384.

7. Bilginoğlu A, Aydın D, Özsoy Ş, Aygün H. Protective effect of melatonin on adriamycin-induced cardiotoxicity in rats. Arch Turk Soc Cardiol. 2014;42:265-273.

8. Broom DM. Transport stress in cattle and sheep with details of physiological and other indicators. Dtsch Tierarztl Wochenschr. 2003;110:83-89.

9. Chacon G, Garcia-Belenguer S, Villarroel M, Maria GA. Effect of transport stress on physiological responses of male bovines. Dtsch Tierarztl Wochenschr. 2006;112:4659 . 
10. Chalmeh A, Akhtar SI, Zarei MH, Badkoubeh M. Electrocardiographic indices of clinically healthy Chios sheep. Veterinary Science Development. 2015;5:99-102.

11. Cockram MS, Kent JE, Jackson RE, Goddard PJ, Doherty OM, McGilp IM, et al. Effect of lairage during $24 \mathrm{~h}$ of transport on the behavioural and physiological responses of sheep. Animal Science. 1997;65:391-402.

12. Çolakoğlu N, Özbeyaz C. Akkaraman ve malya koyunlarının bazı verim özelliklerinin karşılaştırılması. Turk J Vet Anim Sci. 1999;23:351-360.

13. Damtew A, Erega Y, Ebrahim H, Tsegaye S, Msigie D. The effect of long distance transportation stress on cattle: a Review. Biomed J Sci \& Tech Res. 2018;3:1-5.

14. Giovagnoli G, Trabalza Marinucci M, Bolla A. Transport stress in horses: an electromyographic study on balance preservation. Livest Prod Sci. 2002;73:247-254.

15. Grandin T. Assessment of stress during handling and transport. Journal of Animal Science. 1997;75:249-257.

16. Grigor PN, Cockram MS, Steele WB, McIntyre J, Williams CL, Leushuis IE, et al. A comparison of the welfare and meat quality of veal calves slaughtered on the farm with those subjected to transportation and lairage. Livest Prod Sci. 2004;91: 219-228.

17. Hall SJG, Broom DM, Kiddy GNS. Effect of transportation on plasma cortisol and packed cell volume in different genotypes of sheep. Small Ruminant Res. 1998;29: 233-237.

18. Hartung J. Effects of transport on health of farm animals. Vet Res Comm. 2003;27:525-527.

19. Haydardedeoğlu AE, Yağc1 BB, Ural K, Güzelbekteş H. Stress responses of stallions during transport period: the variations of complete blood count and serum biochemistry. Atatürk Univ Vet Bil Derg. 2017;12:118-123.

20. Koncagül S, Akça N, Vural ME, Karataş A, Bingöl M. Zom koyunlanının morfolojik özellikleri. Kafkas Univ Vet Fak Derg. 2012;18:829-837.

21. Kumar BR, Muralidharan MR, Ramesh PV, Sasirekha A. Effect of transport stress on blood profile in sheep. Indian Vet J. 2003;80:511-514.

22. Mir SA, Nazki AR, Raina R. Comparative electrocardiographic studies, and differing effects of pentazocine on ECG, heart and respiratory rates in young sheep and goats. Small Ruminant Res. 2000;37:13-17.

23. Nielsen BL, Dybkjær L, Herskin MS. Road transport of farm animals: effects of journey duration on animal welfare. Animal Journal. 2011;5:415-427.

24. Noyan A. Yaşam ve hekimlikte fizyoloji. Onyedinci baskı. Ankara:Meteksan yayınevi; 2008. p. 977-1102.

25. Onmaz AC, Van den Hoven R, Gunes V, Cinar M, Kucuk O. Oxidative stress in horses after a 12-hours transport period. Rev Med Vet. 2011;162:213-217.

26. Reddy BS, Venkatasivakumar R, Sivajothi S, Reddy YVP. Electrocardiographic abnormalities in young healthy sheep and goats. International Journal of Biological Research. 2014;2:21-22.
27. SPSS Inc. SPSS 22.0 for Windows Evalution Version. 2013.

28. Tajik J, Samimi AS, Shojaeepour S, Jarakani S. Analysis of base-apex lead electrocardiogram in clinically healthy kermani sheep. J Fac Vet Med Istanbul Univ. 2016;42:74-79.

29. Tan H. Atlarda ventrikuler hipertrofi ve kronik kardiyomiyofibrosisleri ortogonal sistem elektrokardiyografi ve vektorkardiyografi yontemleriyle saptama calışmaları. Docentlik tezi, İstanbul. 1981.

30. Terlouw C. Stress reactions at slaughter and meat quality in pigs: genetic background and prior experience. A brief review of recent findings. Livest Prod Sci. 2005;94:125135.

31. Wernicki A, Urban-Chmiel R, Kankofer M, Mikucki P, Puchalski A, Tokarzewski S. Evaluation of plasma cortisol and TBARS levels in calves after short-term transportation. Rev Med Vet. 2006;157:30-34.

32. Yilmaz B. Fizyoloji. İkinci basım, Ankara:Feryal Matbaac1lik; 2000. p. 212-213. 